\title{
Travma sonucu oluşan anterior tek diş eksikliklerinin implant destekli sabit restorasyonlar ile tedavisi: 2 olgu sunumu*
}

\author{
Zinde Güder ${ }^{1}$, Önjen Tak ${ }^{1}$, Bahadır Kan², Fatih Mehmet Coşkunses ${ }^{2}$
}

Selcuk Dental Journal, 2015; 3: 136-143

Başvuru Tarihi: 06 Ağustos 2015 Yayına Kabul Tarihi: 21 Ağustos 2015

\section{ABSTRACT}

Treatment of anterior single tooth loss caused by trauma with implant supported fixed restorations: 2 Case reports

Dentoalveolar traumas are common in young adults especially at the maxillary anterior region. Careful treatment planning and suitable material selection have crucial importance for single-tooth loss caused by traumas to meet the high esthetic expectations of the patient. The aim of this case report is to present the treatment of 2 young adult male patients who have lost their maxillary central incisors because of dentoalveolar trauma by implant retained custom zirconia abutments and zirconia based all-ceramic single crowns.

23 and 18 year-old young male patients have lost their maxillary central incisors caused by dental trauma. One bone level implant for each patient were placed and after the healing period periimplant soft tissue was manipulated. Definitive zirconia based all-ceramic restorations supported by customized zirconia abutments were delivered to the patients.

The patients' aesthetic and functional expectations were achieved. After one-year follow-up no complications were observed.

\section{KEYWORDS}

Aesthetic, custom abutment, dental implant, dental trauma, zirconia

Günümüzde özellikle genç bireylerde estetiğin önemi gittikçe artmaktadır. Bu nedenle hastaların özellikle maksiller anterior bölgedeki restorasyonlardan beklentileri de oldukça yüksektir. Buna ek olarak dentoalveolar travmalardan en çok etkilenen bölge de maksiller kesicilerdir (Caliskan ve Pehlivan 1996). Dental travmalar çoğunlukla 16-20 yaş grubunda ve travma tipi olarak en sık komplike kron-kök kırıkları şeklinde gözlenmektedir (Andreasen ve Andreasen 1994). Bu tip anterior dental travma vakalarında doğal görünümü yakalamak için uygun materyal seçimi ve hassas bir çalışma gerekmektedir. Estetik bölgede yer alan dişlerin eksikliği durumunda estetiği sağlamak amacıyla yapılan implant üstü restorasyonlarda kullanılan materyal seçenekleri de günümüzde çok çeşitlilik kazanmıştır. Standart titanyum abutmentlar yerine, kişiye özel zirkonya abutmentların kullanımı estetik sonuçları arttırmaktadır.

Anterior tek diş eksikliklerinde doğal görünümü sağlamak için bir diğer önemli nokta da doğal yumuşak doku konturları ve papil varlığıdır. Papil oluşumu açısından en kabul görmüş konsept biyolojik aralık konseptidir. Bu konsepte göre papil oluşumu, implantın vertikal ve horizontal konumu, implant protetik parçasının tasarımı, mukoza ile temasta olan materyal (titanyum, seramik, zirkonya vb.), transmukozal komponentin şekil ve konturu, yumuşak doku biyotipi gibi birçok farklı etkene bağlıdır (Hermann ve ark 2000, Grunder ve ark 2005). Yüksek gülme hattı ve ince diş eti biyotipi estetik sonuçlara ulaşılmasını zorlaştıran en önemli faktörlerdendir. Labial kemik kalınlığı da uzun dönemde yumuşak doku konturunun sağlanması ve implantın stabilitesi açısından büyük önem taşımaktadır. Labial kemiğin devamlılığını ve yumuşak doku konturunun uzun dönem başarısını sağlamak amacıyla greft materyallerinin kullanılması başarı oranını arttırmaktadır (Kan ve ark 2003, Mankoo 2004).

\footnotetext{
* Bu olgu sunumu 2014 yılında İstanbul'da düzenlenen 38. EPA Yıllık Kongresi - 21. TPİD Bilimsel Kongresi'nde sunulmuştur.

${ }^{1}$ Kocaeli Üniversitesi Diş Hekimliği Fakültesi Protetik Diş Tedavisi Anabilim Dalı, Kocaeli

${ }^{2}$ Kocaeli Üniversitesi Diş Hekimliği Fakültesi Ağız Diş ve Çene Cerrahisi Anabilim Dalı, Kocaeli
} 
Diş kaybının zamanlaması, kaybedilen dişin periapikal sağlığı gibi durumlar implant yerleşim zamanını etkilemektedir. İmplantın yerleştirilmesi; immediat, gecikmiş immediat (diş çekimini takiben 6 hafta ile 6 ay arasında) ve geç (kemik iyileşmesi tamamlandıktan sonra) implant uygulaması gibi farklı zamanlarda yapılabilir. Eğer gecikmiş immediat veya geç implantasyon yapılacaksa, kemikte gerçekleşecek rezorpsiyonun kontrol edilebilmesi açısından çekim soketinin korunması amacıyla ogmentasyon yapılması gerekmektedir (Darby ve ark 2009). İmmediat implantasyon hastanın cerrahi travmasını önlemek açısından fayda gösterse de özellikle enfeksiyon veya ince bir labial kemik varlığında daha büyük komplikasyonlara yol açabilmektedir. Bu nedenle soket ogmentasyonu yapıldıktan sonra gecikmiş immediat implantasyon var olan kemiğin tamamen değerlendirilmesi ve oluşacak rezorpsiyonun öngörülerek protetik tedavinin planlanması açısından avantaj sağlarken tedavi süresini uzatması en büyük dezavantajıdır (Tal 1999).

$\mathrm{Bu}$ makalede, travma sebebiyle maksiller santral dişini kaybetmiş iki genç erkek hastanın, dental implant ve yumuşak doku rekonstrüksiyonu sonrası kişisel zirkonya abutmentlardan destek alan zirkonya altyapılı tam seramik restorasyonlarla tedavisi kısa dönem sonuçları ile anlatılmaktadır.

\section{OLGU SUNUMU}

\section{OLGU 1}

18 yaşında erkek hasta diş eksikliği şikayeti ile Kocaeli Üniversitesi Diş Hekimliği Fakültesi Protetik Diş Tedavisi Anabilim Dalı Kliniği'ne başvurdu. Herhangi bir sistemik hastalığı bulunmayan hasta klinik ve radyografik olarak incelendi. Hastanın anamnezinde 1 yıl önce geçirmiş olduğu dentoalveolar travma sebebiyle maksiller sol santral dişini kaybettiği; maksiller sağ santral ve lateral, sol lateral ile mandibular sağ santral dişlerinde ise kron kırıkları oluştuğu ve travma sonrasında herhangi bir tedavi görmediği öğrenildi (Resim 1). Ek olarak hastada düşük gülme hattı varlığı gözlendi. Hasta tedavi seçenekleri konusunda bilgilendirildi ve aydınlatılmış onamı alınarak implant destekli bir restorasyon yapılmasına karar verildi.

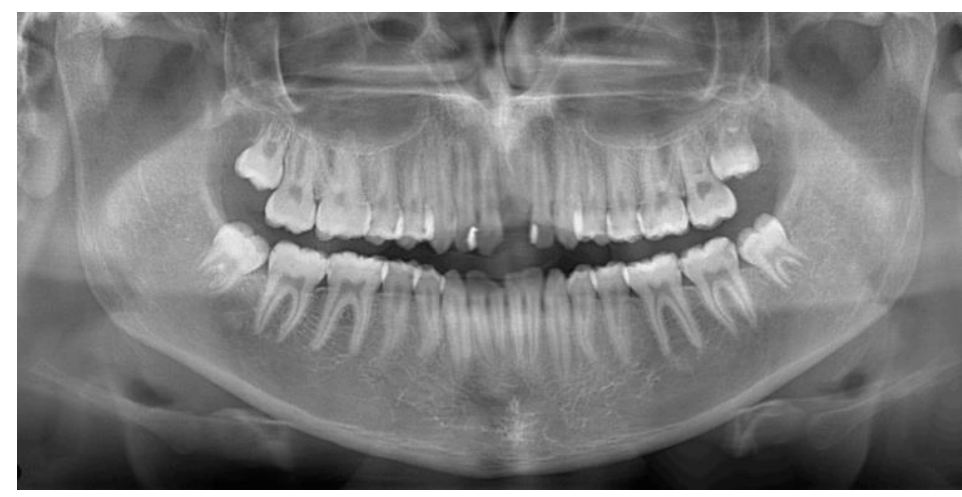

Resim 1.

Başlangıç panoramik radyografisi

Illk olarak hastanın kron kırıkları kompozit rezin (Clearfil Majesty, Kuraray, Japonya) ile restore edildi (Resim 2).

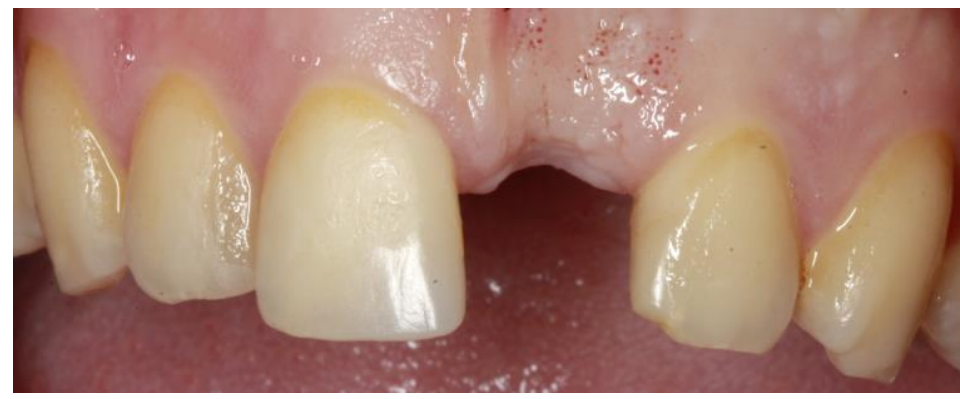

Resim 2.

Kron kırıklarının kompozit rezin ile restorasyonu sonrası ağız içi görünüm

Çalışma modellerini elde etmek amacıyla aljinat ölçü maddesi (CA37, Cavex, Hollanda) ile ölçüleri alındı ve elde edilen modeller üzerinde cerrahi plak hazırlandı (Resim 3).

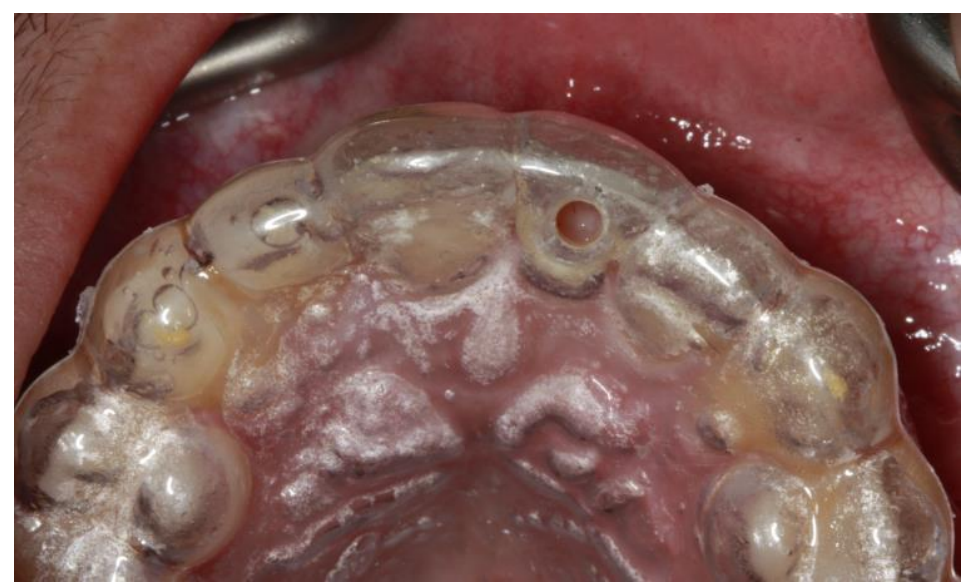

Resim 3.

Cerrahi plağın ağızda provası

Daha sonra cerrahi rehber plak yardımı ile kemik seviyesinde, dar çaplı bir implant $(3.3 \times 12 \mathrm{~mm}$, Straumann $A G$, İsviçre) ideal implant pozisyonu kuralları dahilinde yerleştirildi (Resim 4). 


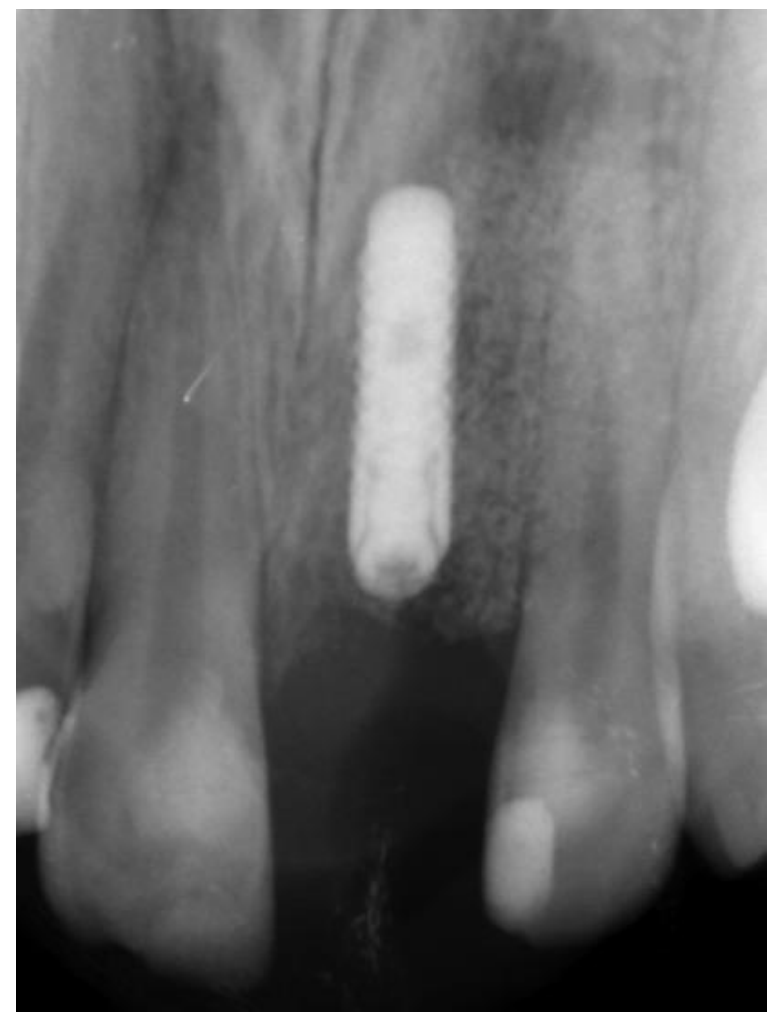

Resim 4.

İmplant yerleşimi sonrası periapikal radyografi

Kayıp diş bölgesindeki yumuşak ve sert doku konturundaki yetersizlik değerlendirilerek aynı seansta xenogreft (Cerabone, Botiss, Almanya) ve kollojen membran (Collprotect-Botiss, Almanya) ile palatinalden saplı bağ dokusu grefti uygulandı. Dört aylık sorunsuz iyileşme sürecinden sonra 2. cerrahi ile implantın üzeri açıldı ve iyileşme parçası (Straumann bone level NC healing abutment, İsviçre) yerleştirildi. Daha sonra birer haftalık aralarla iyileşme başlığının etrafına akışkan kompozit rezin (Clearfil Majesty Flow, Kuraray) eklenerek çıkış profili şekillendirilmeye başlandı (Resim 5).

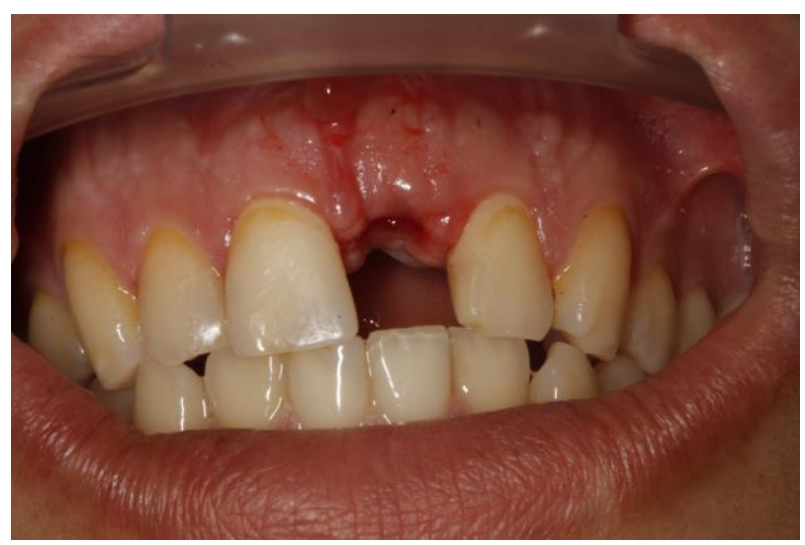

Resim 5.

Dişeti şekillendirmesi öncesi
Şekillendirme işlemi için iyileşme başlığının etrafına sirküler olarak eklenen akışkan kompozit hasta ağzında kontrol edildi (Resim 6, Resim 7).

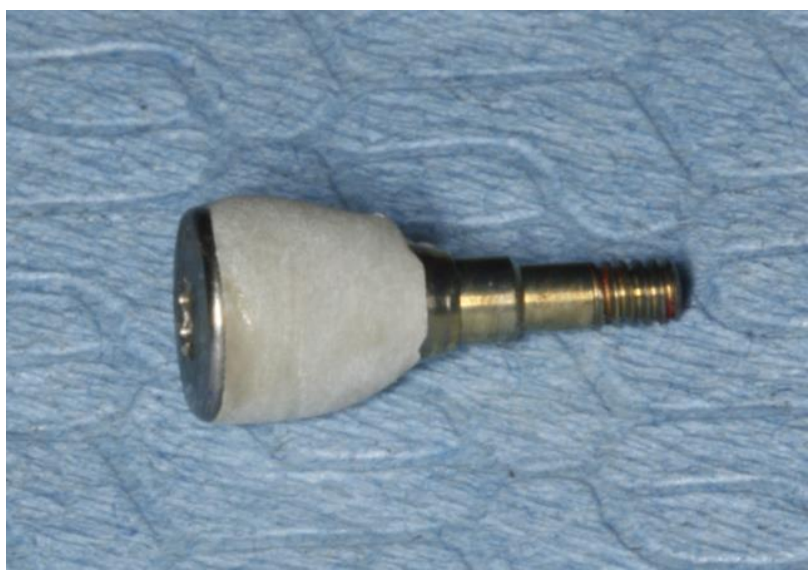

Resim 6.

Dişeti şekillendirmesi için iyileşme başlığının etrafına akışkan kompozit rezin uygulaması

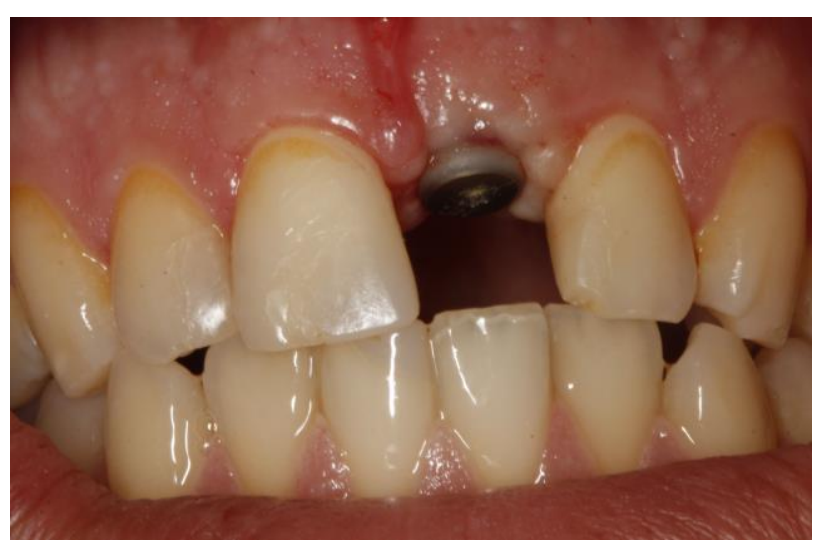

Resim 7.

İyileşme başlığının dişetinde oluşturduğu staz

Diş etinde oluşan staz 5 dakikalık süre ile gözlemlendi. Kaybolmaması durumunda eklenen kompozit aşındırılarak uyumlandırıldı. Son formu verilen iyileşme başlığı cila diskleri ile cilalanarak yerleştirildi. Şekillendirmeye üst anterior dişlerin zenith noktalarında simetrinin sağlandığı 4. seansta son verildi (Resim 8, Resim 9). Daha sonra kapalı kaşık ölçü postu ve polieter ölçü maddesi (Impregum, 3M Espe, Seefeld, Almanya) kullanılarak daimi ölçü alındı. Model elde edildikten sonra kişiye özel zirkonya abutment üretildi ve ağızda provaları yapıldı (Resim 10). Sonrasında CAD/CAM zirkonya altyapılı tam seramik restorasyon üretildi ve ağızda estetik, fonksiyon, fonasyon, marjinal uyum ve okluzyon kontrolleri yapıldı. Glazür ve makyaj işlemlerinden sonra çinko polikarboksilat siman (Adhesor Carbofine, Spofa Dental, Almanya) kullanılarak simante edildi (Resim 11). Hasta ağız bakımı konusunda motive edildi ve düzenli kontrollere çağırıldı. 


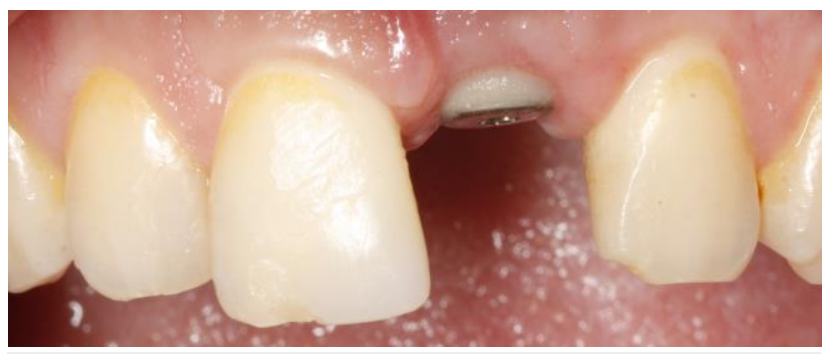

Resim 8.

Dişeti şekillendirmesi (3. hafta)

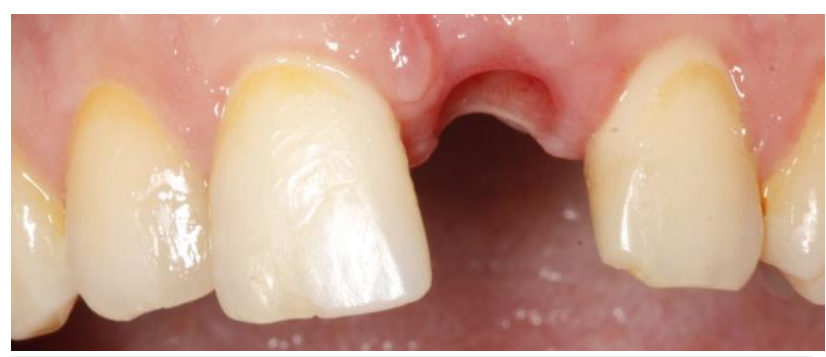

Resim 9.

Dişeti şekillendirmesi sonrası dişetinin epitelizasyonu (4. hafta)

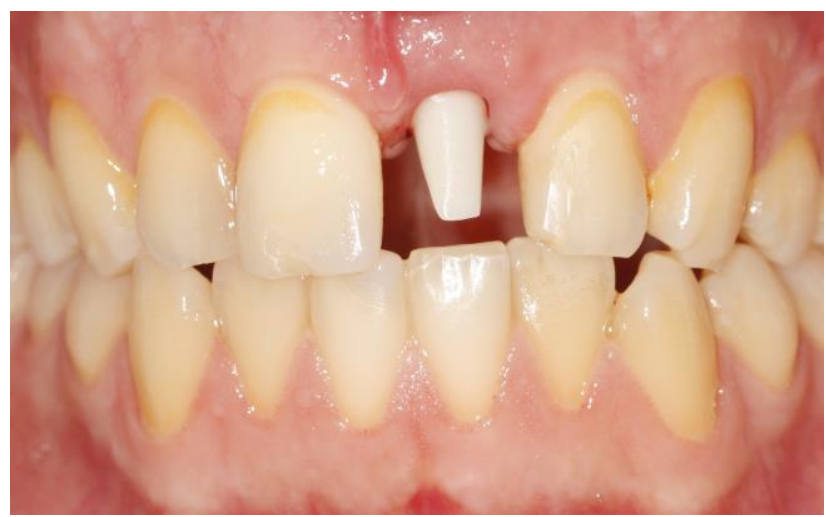

Resim 10.

Kişiye özel üretilen zirkonya abutment

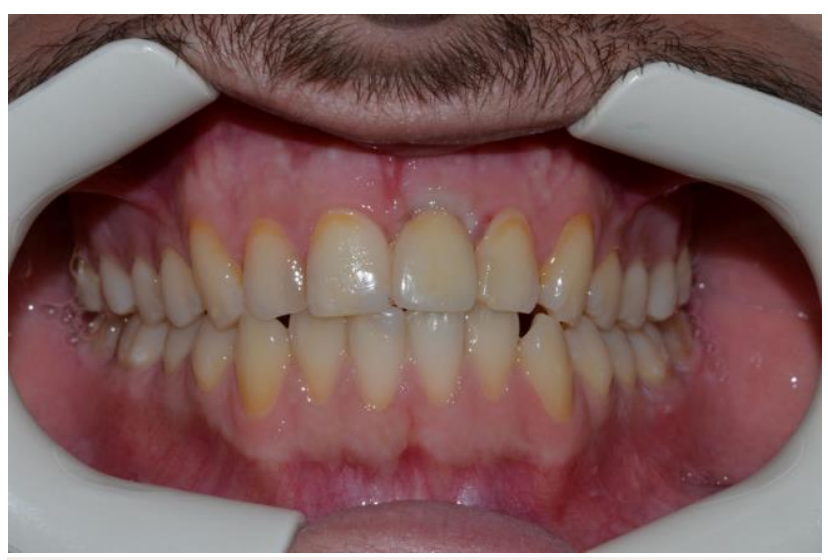

Resim 11.

Simantasyon sonrası restorasyonun ağız içi görünümü
Yapılan 1. 3. 6. ve 12. ay kontrollerinde herhangi bir biyolojik, biyomekanik, fonksiyonel ve estetik komplikasyonla karşılaşılmadı. Ancak plak birikimi nedeniyle ileride oluşabilecek komplikasyonlara karşı hasta bilgilendirildi ve ağız bakımı konusunda tekrar motive edildi. Hasta estetik ve fonksiyonel sonuçlardan son derece memnun kaldı (Resim 12, Resim 13).

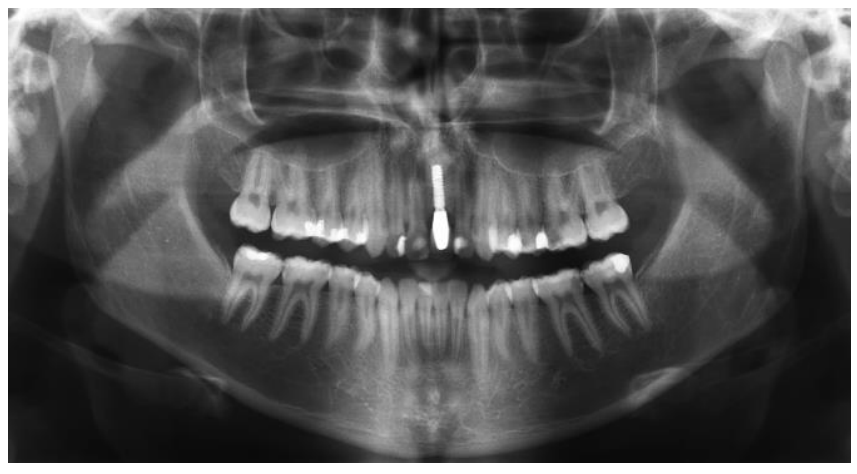

Resim 12.

Bir yıllık takip - panaromik radyografi

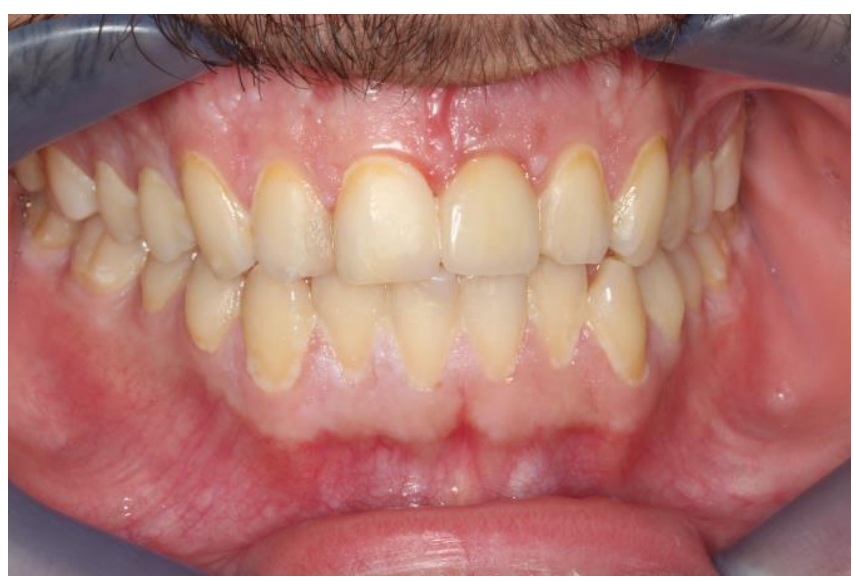

Resim 13.

Bir yıllık takip - ağız içi görünüm

\section{OLGU 2}

23 yaşında erkek hasta maksiller anterior bölgede yaşadığı dentoalveolar travma sebebi ile Kocaeli Üniversitesi Diş Hekimliği Fakültesi Protetik Diş Tedavisi Anabilim Dalı Kliniği'ne başvurdu. Herhangi bir sistemik rahatsızlığı bulunmayan hastanın klinik ve radyografik muayenesi sonucunda, maksiller sağ santral dişte travmaya bağlı internal rezorpsiyon tespit edildi (Resim 14). Ayrıca düşük gülme hattı ve uygun olmayan okluzal kontaklar değerlendirildi ve hastaya ortodontik tedavi tavsiye edildi. Ortodontik tedaviyi reddeden hasta diş çekiminin ardından tercih edilebilecek tedavi seçenekleri konusunda bilgilendirildi ve aydınlatımış onamı alınarak implant destekli bir restorasyon yapılmasına karar verildi. 


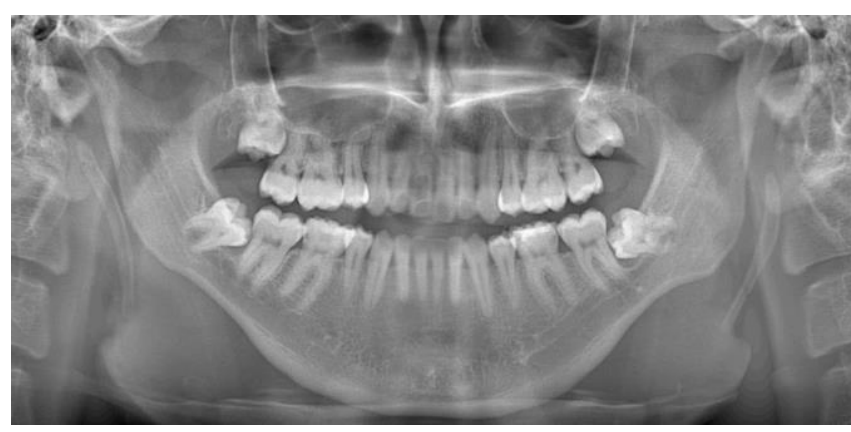

Resim 14.

Başlangıç panoramik radyografisi, maksiller sağ santral dişte travmaya bağlı internal rezorpsiyon

Hastanın diş çekiminin ardından soket morfolojisinin korunması için xenogreft (Cerabone, Botiss, Almanya) ve serbest dişeti grefti kullanılarak soket koruma (socket preservation) yapıldı ve gecikmiş implantasyon planlandı. Diş çekiminden 1 hafta sonra hastanın çalışma modellerini elde etmek amacıyla aljinat ölçü maddesi (CA37, Cavex, Hollanda) ile ölçüleri alındı ve elde edilen modeller üzerinde cerrahi rehber plak hazırlandı. 6 aylık iyileşme periyodundan sonra hastaya rehber plak yönlendirmesi ile bukkal kemikten $2 \mathrm{~mm}$ palatinalde konumlanacak şekilde kemik seviyesinde, dar çaplı bir implant $(3.3 \times 10 \mathrm{~mm}$, Straumann AG, İsviçre) yerleştirildi (Resim 15).

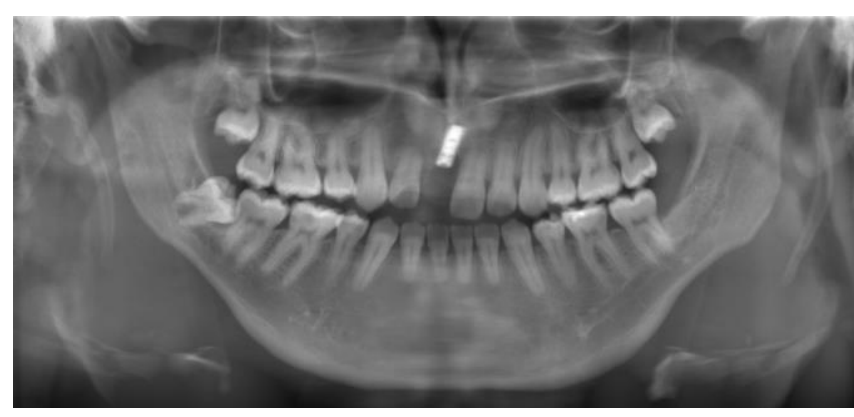

Resim 15.

İmplant yerleşimi sonrası panoramik radyografi

İki aylık iyileşme sürecinden sonra 2. cerrahi ile implantın üzeri açıldı ve iyileşme parçası (Straumann bone level NC healing abutment, İsviçre) yerleştirildi. $\mathrm{Bu}$ aşamada hastaya yumuşak doku konturlarının düzenlenmesi için gingivektomi ve greft uygulamaları önerildi fakat hasta tarafından reddedildi. Daha sonra birer haftalık aralarla iyileşme başlığının etrafına akışkan kompozit rezin (Clearfil Majesty Flow, Kuraray, Japonya) eklenerek çıkış profili şekillendirilme sürecine geçildi (Resim 16).

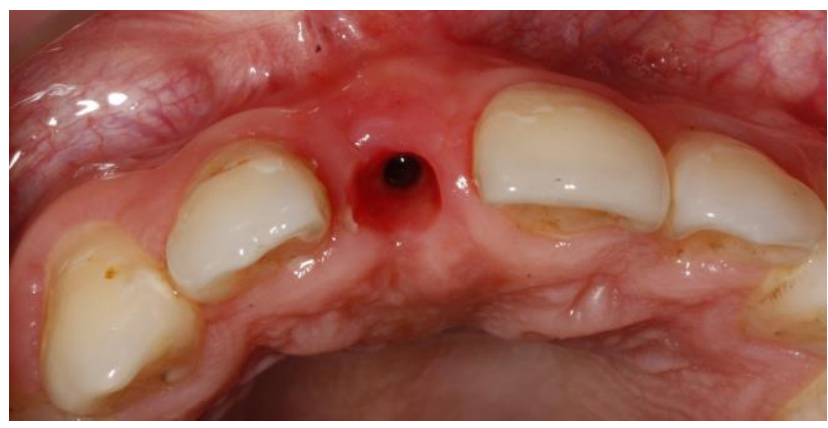

Resim 16.

Dişeti şekillendirmesi öncesi

Şekillendirme işlemi yukarıda anlatıldığı şekilde gerçekleştirildi. 3 haftalık şekillendirme sonunda hastanın isteği üzerine düşük gülme hattı da göz önüne alınarak şekillendirmeye son verildi (Resim 17).

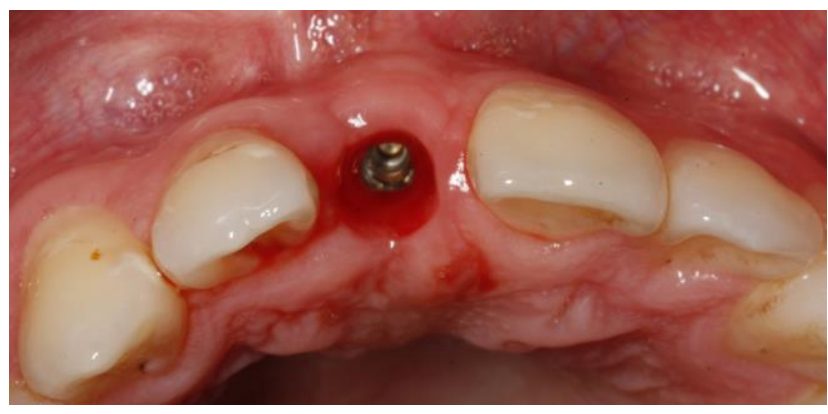

Resim 17.

Dişeti şekillendirmesi sonrası

Kapalı kaşık ölçü postu implanta yerleştirildi ve polieter ölçü maddesi (Impregum, 3M Espe, Almanya) kullanılarak daimi ölçü alındı. Elde edilen model üzerinde şekillendirilen dişeti konturlarına uygun kişiye özel zirkonya abutment üretildi ve ağızda gerekli provaları (Resim 18) yapıldıktan sonra CAD/CAM zirkonya altyapılı tam seramik restorasyon üretildi. Restorasyonun ağızda estetik, fonksiyon, fonasyon, marjinal uyum ve okluzyon kontrolleri yapıldı. Glazür ve makyaj işlemlerinden sonra çinko polikarboksilat siman (Adhesor Carbofine, Spofa Dental, Almanya) kullanılarak simante edildi (Resim 19). Hasta ağız bakımı konusunda motive edildi ve düzenli kontrollere çağırıldı.

Yapılan 1. 3. 6. ve 12. ay kontrollerinde herhangi bir komplikasyonla karşılaşılmadı. Hastanın estetik ve fonksiyonel beklentileri başarıı bir şekilde karşılandı (Resim 20, Resim 21). 


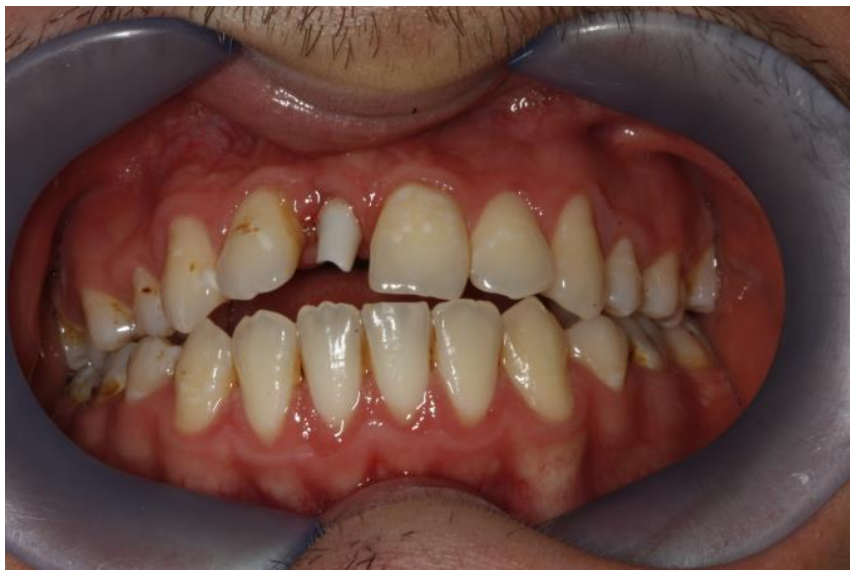

Resim 18.

Kişiye özel üretilen zirkonya abutment

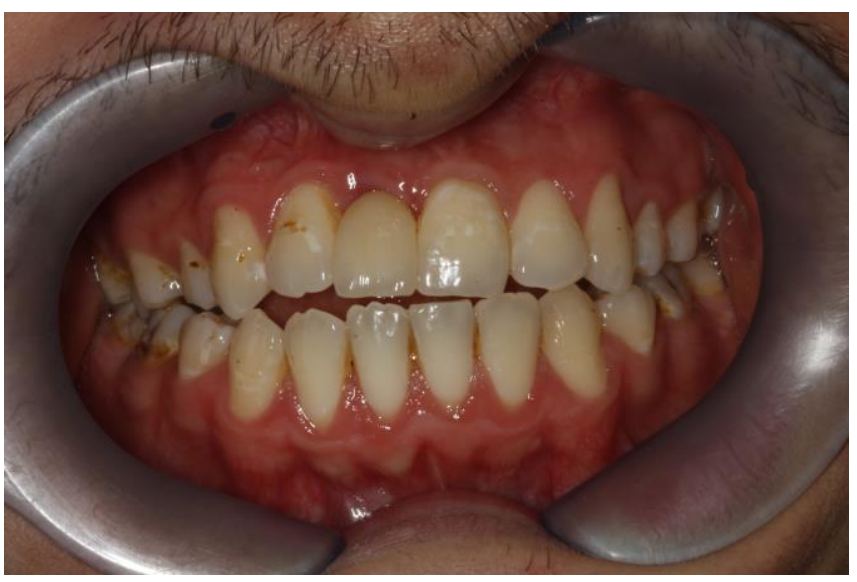

Resim 19.

Simantasyon sonrası restorasyonun ağız içi görünümü

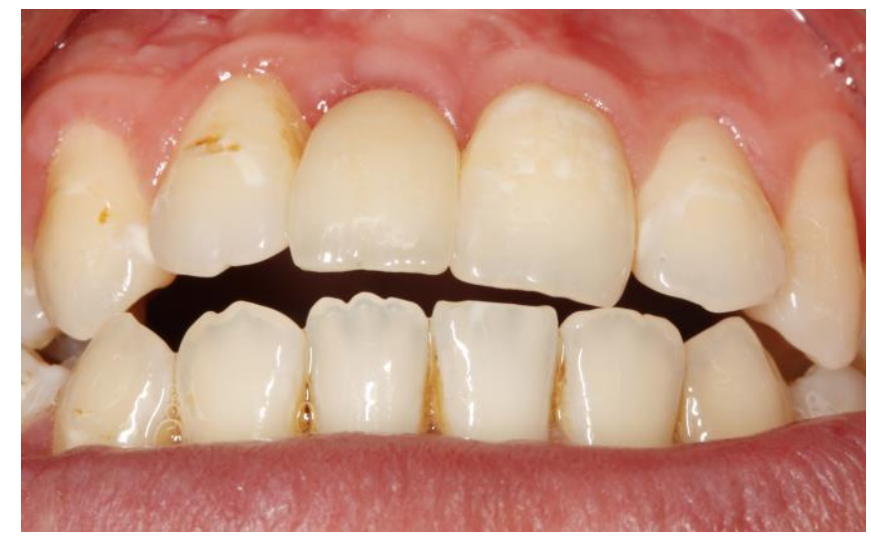

Resim 20

Bir yıllık takip - ağız içi görünüm

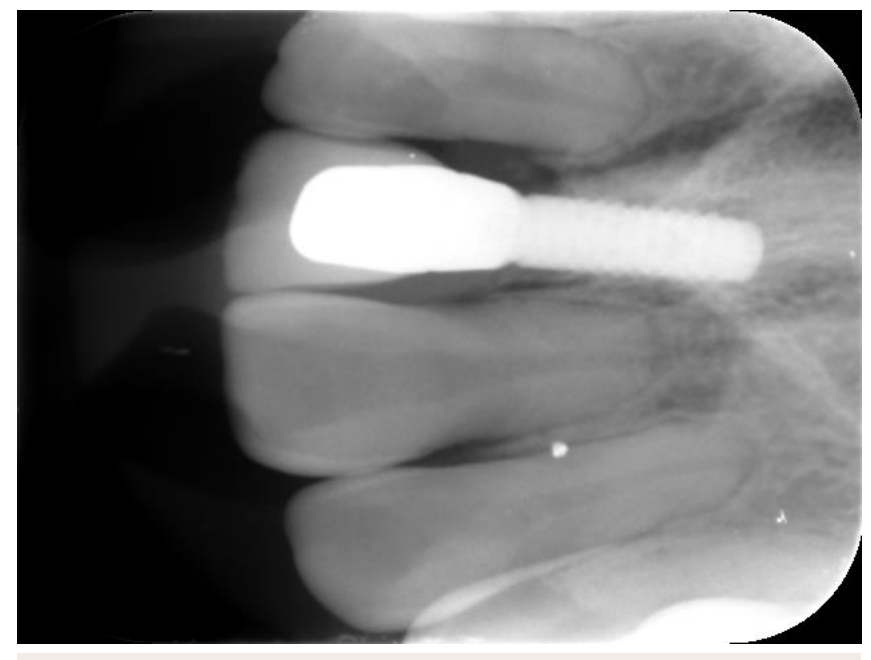

Resim 21

Bir yıllık takip - periapikal radyografi

\section{TARTIŞMA}

Anterior bölge tek diş eksikliklerinde çok çeşitli tedavi seçenekleri bulunmaktadır. Konvansiyonel köprüler, adeziv köprüler, kanatlı köprüler ve implant uygulamaları gibi tedavi seçenekleri değerlendirilirken; hastanın yaşı, estetik beklentileri, maddi durumu, yumuşak ve sert doku konturları gibi değişkenler göz önünde bulundurularak tedavi planlaması yapılmalıdır. Estetik bölgedeki tek diş eksikliklerinde dental implant uygulamaları dikkatli bir planlama ve özenli bir çalışma sonucunda hasta beklentilerini karşılarken, konservatif bir yaklaşım ortaya koymaktadır. Bu doğrultuda ideal implant pozisyonu belirlenirken, protez yönlendirmeli 3 boyutlu planlama yapılması son derece önemlidir (Buser ve ark 2004, Funato ve ark 2007). Bu amaçla üretilen cerrahi plakların yardımı ile yönlendirilen implant pozisyonları, mine-sement sınırının $3 \mathrm{~mm}$ apikali ve bukkolingual olarak bukkal kemiğin $2 \mathrm{~mm}$ palatinalinde olacak şekilde konumlandırıldı.

Yumuşak doku çıkış profili şekillendirmeleri yapılacak restorasyonun formunda belirleyicidir. $\mathrm{Bu}$ şekillendirme immediat geçici restorasyonlar veya standart diş eti şekillendirici parçalar ile yapılabilmektedir (Valentini ve ark 2010). Şekillendirmede akrilik rezine göre çok daha üstün doku yanıtı sağlayan düşük viskoziteli akışkan kompozit rezinler sıklıkla tercih edilmektedir. Geçici restorasyon ya da standart diş eti şekillendirici parçalar üzerine kompozit rezinin küçük parçalar halinde uygulanması ve katmanlar halinde polimerize edilmesi tavsiye edilmektedir (Edelhoff ve ark 2002). Şekillendirmede ülserasyonları ve diş eti çekilmesini önlemek için kademeli basınç uygulanmalı; tatmin edici bir sonuç elde etmek için mümkün olduğunca 
düşük basınçlar kullanılmalı ve şekillendirme birkaç klinik seansta yapılmalıdır. Bu işlemin mümkün olduğu kadar cerrahi ikinci faz sonrasında yapılması tavsiye edilmektedir. Şekillendirmenin birinci cerrahi aşamada yapıldığında ilerleyen dönemlerde bir miktar diş eti çekilmesi ile karşılaşılabileceği bildirilmektedir (Nascimento ve ark 2012). Bu olgu sunumunda yer alan vakalarda greftleme yapılması nedeniyle 2 aşamalı cerrahi teknik kullanıldığı için immediat bir geçici yapılamamış ve bu nedenle osseointegrasyon sonrasında yumuşak doku şekillendirmesine geçilmiştir. Şekillendirme literatüre uygun şekilde birer haftalık aralarla iyileşme başlığının etrafına dişetinde kalıcı staz yapmayacak miktarlarda akışkan kompozit rezin eklenerek yapıldı.

Hastaların estetik beklentileri günümüzde giderek artmaktadır. Dental ekipman ve malzemelerde yaşanan gelişmeler bu beklentilerin karşılanmasında önemli role sahiptirler. $\mathrm{Bu}$ nedenle tam seramik sistemler ve zirkonya abutmentlar son dönemde sıklıkla tercih edilmektedir. Titanyumun aksine zirkonyanın doğal dişe yakın rengi ve translusentliği sayesinde doğal dişe benzer restorasyonlar üretebilmek kolaylaşmıştır. Maksiller anterior bölgede kişiye özel zirkonya abutmentlar ve tam seramik restorasyonlar ile tedavi edilen hastaların estetik sonuçlardan son derece memnun kaldıkları araştırmacılar tarafından bildirilmiştir (Lee ve Hasegawa 2008). Kişiye özel CAD/CAM zirkonya abutmentlar, yapılan yumuşak doku şekillendirmesi sonucunda elde edilen son konturları ve dolayısı ile çıkış profilini ideal şekilde desteklemektedir. Ayrıca diş benzeri rengi sayesinde ince dişeti biyotipi olan hastalarda gri renk yansıması yaşanmaması ve olası bir yumuşak doku çekilmesi durumunda estetik kayıpların minimize edilmesinde de yardımcı olmaktadır. Sunulan her iki olguda da yerleştirilen implantlar estetik üstünlükleri ortaya konulmuş olan zirkonya abutmentlar ve zirkonya alt yapılı tam seramik kronlar ile restore edildi ve 1 yıllık takip sonucunda hastaların estetik beklentilerini karşılayan başarılı sonuçlar elde edildi.

Maksiller anterior bölge tek diş eksikliklerinde implant destekli restorasyonlar son derece başarılı bir tedavi seçeneği olarak tercih edilebilir. Kişiye özel üretilen zirkonya abutmentlar ve tam seramik restorasyonlar ile hastaların yüksek estetik beklentileri karşılanabilmekte ve başarılı sonuçlar elde edilebilmektedir.

\section{ÖZET}

Travma sonucu oluşan anterior tek diş eksikliklerinin implant destekli sabit restorasyonlar ile tedavisi: 2 olgu sunumu

Dentoalveolar travmalar genç bireylerde ve özellikle maksiller anterior bölgede sıklıkla karşılaşılan olgulardandır. Bu travmalar sonucu oluşan tek diş eksikliklerinde hastaların yüksek estetik beklentilerini karşılamak için uygun materyal seçimi ve detaylı bir planlama büyük önem arz etmektedir. Bu olgu sunumunun amacı dentoalveolar travma sonucu maksiller santral dişini kaybetmiş 2 genç erkek hastanın implant destekli, kişiye özel üretilmiş zirkonya abutmentlar üzerine uygulanan zirkonya altyapılı tam seramik tek kronlar ile tedavisini sunmaktır.

23 ve 18 yaşında iki genç erkek hasta geçirdikleri dental travma sebebi ile maksiller santral dişlerini kaybetmiştir. Her iki hastaya birer adet kemik seviyesi implant yerleştirildi ve iyileşme sonrası yumuşak doku şekillendirmesi yapıldı. Kişiye özel olarak üretilen zirkonya abutmentlardan destek alan zirkonya altyapılı tam seramik restorasyonlar hastalara teslim edildi.

Hastaların estetik ve fonksiyonel beklentileri karşılandı. 1 yıllık takip sonunda herhangi bir komplikasyonla karşılaşılmadı.

\section{ANAHTAR KELIMELER}

Dental implant, dental travma, estetik, kişiye özel abutment, zirkonya

\section{KAYNAKLAR}

Andreasen FM, Andreasen JO, 1994. Root fractures, In: Textbook and color atlas of traumatic injuries to the teeth, Ed; Andreasen JO, Andreasen FM, Third Edition, Munksgaard Publishers, Copenhagen, Denmark, pp; 279-314.

Buser D, Martin W, Belser UC, 2004. Optimizing esthetics for implant restorations in the anterior maxilla: anatomic and surgical considerations. Int $\mathrm{J}$ Oral Maxillofac Implants, 19, 43-61.

Caliskan MK, Pehlivan Y, 1996. Prognosis of rootfractured permanent incisors. Endod Dent Traumatol, $12,129-136$.

Darby I, Chen ST, Buser D, 2009. Ridge preservation techniques for implant therapy. Int $\mathrm{J}$ Oral Maxillofac Implants, 24, 260-271.

Edelhoff D, Spiekermann H, Yildirim M, 2002. A review of esthetic pontic options. Quint Int, 33, 736-746. 
Funato A, Salama MA, Ishikawa T, Garber DA, Salama H, 2007. Timing, positioning, and sequential staging in esthetic implant therapy: A four-dimensional perspective. Int $\mathrm{J}$ Periodontics Restorative Dent, 27, 313-323.

Grunder U, Gracis S, Capelli M, 2005. Influence of the 3-D bone-to-implant relationship on esthetics. Int $\mathrm{J}$ Periodontics Restorative Dent, 25, 113-119.

Hermann JS, Buser D, Schenk RK, Higginbottom FL, Cochran DL, 2000. Biologic width around titanium implants. A physiologically formed and stable dimension over time. Clin Oral Implants Res, 11, 1-11.

Kan JY, Rungcharassaeng K, Umezu K, Kois JC, 2003. Dimensions of peri-implant mucosa: an evaluation of maxillary anterior single implants in humans. J Periodontol, 74, 557-562.

Lee CY, Hasegawa H, 2008. Immediate load and esthetic zone considerations to replace maxillary incisor teeth using a new zirconia implant abutment in the bone grafted anterior maxilla. J Oral Implantol, 34, 259-267.

Mankoo T, 2004. Contemporary implant concepts in aesthetic dentistry-Part 2: Immediate single-tooth implants. Pract Proced Aesthet Dent, 16, 61-68.

Nascimento PLA, Rocha DN, Maia JBO, Coimbra L, Dias AHM, 2012. Peri-implant esthetics through gingival conditioning. Rev Gaúcha Odontol, 60, 516-522.

Nevins M, Camelo M, De Paoli S, Friedland B, Schenk RK, Parma-Benfenati S, Simion M, Tinti C, Wagenberg B, 2006. A study of the fate of the buccal wall of extraction sockets of teeth with prominent roots. Int J Periodontics Restorative Dent, $26,19-29$.

Tal H, 1999. Autogenous masticatory mucosal grafts in extraction socket seal procedures: a comparison between sockets grafted with demineralized freeze-dried bone and deproteinized bovine bone mineral. Clin Oral Implants Res, 10, 289-296.

Valentini P, Abensur D, Albertini JF, Rocchesani M, 2010. Immediate provisionalization of single extraction-site implants in the esthetic zone: a clinical evaluation. Int $\mathrm{J}$ Periodontics Restorative Dent, 30, 41-51.

Yazışma Adresi:

Yrd.Doç.Dr.Önjen TAK

Kocaeli Üniversitesi Yuvacık Yerleşkesi

Diş Hekimliği Fakültesi Protetik Diş Tedavisi A.D.

41190 Yuvacık, Başiskele / KOCAELi

Tel: +902623442111

Faks: +902623442109

E-mail: onjentak@hotmail.com 